\title{
Enoxaparin-Induced Liver Injury: Case Report and Review of the Literature and FDA Adverse Event Reporting System (FAERS)
}

\author{
Katherine J. Hahn ${ }^{1} \cdot$ Shannon J. Morales ${ }^{1} \cdot$ James H. Lewis $^{2}$
}

Published online: 17 November 2015

(c) The Author(s) 2015. This article is published with open access at Springerlink.com

\begin{abstract}
Anticoagulants are a well known cause of druginduced liver injury (DILI). We recently encountered a 45-year-old male who developed DILI during treatment with enoxaparin, a low-molecular-weight heparin (LMWH), for dural venous thrombosis. The man received enoxaparin $80 \mathrm{mg}$ subcutaneously, twice daily. After 4 days, the patient was asymptomatic but he developed liver aminotransferase elevations: AST $340 \mathrm{U} / \mathrm{L}$ and ALT 579 U/L. Investigation revealed an R ratio of 19.9 by day 5 and a Roussel Uclaf Causality Assessment Method score of 10 , giving a high probable likelihood that enoxaparin was the cause of hepatic injury. Enoxaparin was discontinued on day 7, and 1 week later AST and ALT had decreased to 61 and $273 \mathrm{U} / \mathrm{L}$, respectively. This case prompted a literature search and a review of the FDA Adverse Event Reporting System (FAERS) database for the range of hepatic adverse events (HAEs) associated with this class. A MEDLINE/PubMed search was conducted using DILI terms and cross-referenced with the anticoagulant classes. A Freedom of Information Act (FOIA) request was also made to identify adverse events (AEs) associated with enoxaparin in FAERS. Case type, severity of outcome, and demographic information were analyzed. Five publications have reported DILI with enoxaparin. Trial data found
\end{abstract}

Katherine J. Hahn

katherine.j.hahn@medstar.net

1 Department of Internal Medicine, Medstar Georgetown University Hospital, 3800 Resevoir Road, NW, PHC Floor \#5, Washington, DC 20007, USA

2 Department of Gastroenterology and Hepatology, Medstar Georgetown University Hospital, Washington, DC, USA elevations in ALT $>3$ times the upper limit of normal (ULN) for unfractionated heparins (UFH) and LMWH in 8 and $4-13 \%$ of subjects, respectively. However, liver injury in all cases was mild, self-limited, and asymptomatic. Our FOIA request yielded 8336 adverse events related to enoxaparin over a 14-year period (Jan 2000-Sept 2014). Specific HAEs were found in $4 \%$ of reports, but all were described with other serious adverse events. The reported outcomes of hospitalization (75\%), death (17\%), and lifethreatening medical events $(5 \%)$ were likely due to other related serious adverse events such as hemorrhage $(28 \%)$ and thrombocytopenia (11\%). We conclude that LMWHrelated liver injury is uncommon and reversible. The mechanism of liver injury is not known, although an idiosyncratic effect is postulated. Although the FAERS database lists hepatic injury in $4 \%$ of all enoxaparin-related AEs, it appears that serious outcomes are related to non-hepatic events.

\section{Key Points}

Drug induced liver injury (DILI) associated with low-molecular-weight heparins (LMWH) has a hepatocellular pattern of injury, short latency (days to weeks), rarely causes symptoms, and is not associated with features of hypersensitivity.

The mechanism of liver injury is not known, though an idiosyncratic direct toxic effect is postulated.

The FDA adverse event reporting system (FAERS) database indicates that $4 \%$ of all enoxaparin-related adverse events involve hepatic injury; however, all serious outcomes are related to non-hepatic events. 


\section{Introduction}

Unfractionated heparins (UFH) are naturally occurring biologic molecules, widely used for anticoagulation [1]. Low-molecular-weight heparins (LMWH), the breakdown product of UFH, have smaller and more uniform weights than UFH allowing for a more predictable antithrombotic effect [2]. LMWH are commonly utilized instead of UFH because of their perceived improved safety profile [3]. When LMWH are used for the treatment and prophylaxis of thromboembolic disorders, the most commonly reported adverse effects from clinical trial data include major bleeding (1.5-2 \%) and thrombocytopenia $(0.1 \%)$ [4]. Another potentially important but less commonly reported adverse effect of LMWH is drug-induced liver injury (DILI), defined as aspartate aminotransferase (AST) and/or alanine aminotransferase (ALT) $>3$ times the upper limit of normal (ULN) [4].

Anticoagulant therapies of different classes have long been identified as a cause of DILI [5-8]. The heparin subclass, in particular, has the highest frequency of anticoagulant-associated hepatic adverse events (HAEs). UFH are reported to cause liver injury in $8 \%$ of patients, while LMWH are implicated in 4-13\% of recipients [4, 9, 10]. In contrast, most other forms of anticoagulation are less likely to cause DILI; only 1-3\% of patients on coumarins (warfarin) [7, 11], 1.5-3\% on factor Xa inhibitors (fondaparinux, apixaban, rivaroxaban) [12-14], and 1.5-3\% of patients on available direct thrombin inhibitors (dabigatran) [15].

An important exception to this low risk of hepatotoxicity from anticoagulants was seen with ximelagatran, one of the first oral direct thrombin inhibitors. Ximelagatran was associated with a far higher incidence of hepatic injury in its long-term treatment trials, approaching $8 \%$ of subjects with ALT and AST $>3 \times$ ULN, $4.7 \%>5 \times \mathrm{ULN}$, and $1.9 \%>10 \times$ ULN [16]. All of these percentages were far higher than ALT elevations seen with the comparator [16]. Unlike DILI from other anticoagulants, ximelagatran-related hepatic damage had a longer latency and sometimes progressed despite withdrawal of the medication [16]. As a result, despite a promising benefit to prevent stoke, ximelagatran was never approved in the US [17] and was eventually removed from the global marketplace due to the risk of severe liver injury [18].

Since then, there has been increased attention paid to the potential hepatoxicity of anticoagulants. However, cases of HAEs from anticoagulants, like other drug classes, are likely under-reported [19-21], and this appears to be the case for both UFH and LMWH. Most published reports have been limited to individual cases or small case series. In this context, we recently encountered a case of severe
DILI attributed to the LMWH, enoxaparin. This prompted us to perform a literature search for other published cases of liver injury related to LMWH, and more specifically, HAEs attributed to enoxaparin. In addition, we also undertook a review of the FDA Adverse Event Reporting System (FAERS) database to identify other post-marketing cases of HAEs related to enoxaparin.

\section{Case Report}

A 45-year-old previously healthy African-American male presented with several months of persistent right-sided headaches and was found on admission to have a dural venous thrombosis on MRI/MRV. He had taken no medications. He was initially started on a heparin drip and was soon converted to the standard dose of enoxaparin at $1 \mathrm{mg} /$ $\mathrm{kg}$, subcutaneously twice a day. At that time, his aminotransferase values were normal $(<40 \mathrm{U} / \mathrm{L})$ with an AST level of $29 \mathrm{U} / \mathrm{L}$ and ALT of $33 \mathrm{U} / \mathrm{L}$. As seen in Table 1, all other laboratory test values including albumin, bilirubin, alkaline phosphatase, gamma-glutamyl transferase (GGT), and international normalized ratio (INR) were also normal. Four days after initiation of enoxaparin, the patient's liver aminotransferases were found to be elevated: AST $340 \mathrm{U} / \mathrm{L}$ and ALT $579 \mathrm{U} / \mathrm{L}$. They continued to increase over the next 2 days, peaking on day 7 with an AST of $460 \mathrm{U} / \mathrm{L}$ and ALT of $770 \mathrm{U} / \mathrm{L}$. An R ratio, the initial step of the Roussel Uclaf Causality Assessment Method (RUCAM), was calculated from laboratory values on day 5 and found to be 19.9-consistent with a hepatocellular pattern of liver injury [22]. The specifics of this calculation are shown in Table 1.

Abdominal ultrasound with Doppler showed patent hepatic and portal vessels with no steatosis. Acute viral hepatitis serologies for hepatitis A, B, and C, as well as Epstein-Barr virus and cytomegalovirus, were all found to be negative. Autoantibodies including antinuclear antibody, anti-smooth muscle antibody, and anti-mitochondrial antibody were also negative. The patient was not genotyped for any DILI biomarkers. The patient had no risk factors for non-alcoholic fatty liver disease, no history of alcohol abuse, no malnutrition, no recent exposures to anyone with hepatic disease, and no episodes of severe hypotension or congestive heart failure.

Although the patient remained asymptomatic and albumin, bilirubin, alkaline phosphatase, GGT, and INR all continued to be normal, enoxaparin was discontinued on day 7 and fondaparinux, a synthetic Xa inhibitor, was started.

On day 13, 6 days after enoxaparin was discontinued and fondaparinux was initiated, AST and ALT had 
Table 1 Clinical laboratory values of our patient

\begin{tabular}{|c|c|c|c|c|c|c|c|c|}
\hline \multirow[t]{2}{*}{ Variable } & \multirow[t]{2}{*}{ Normal range } & \multicolumn{7}{|c|}{ Case report day ${ }^{\mathrm{a}}$} \\
\hline & & 0 & 1 & 5 & 6 & 7 & 13 & 22 \\
\hline INR & $0.8-1.2$ & 1.2 & NA & 1.1 & 1.1 & 1.0 & 1.1 & 1.2 \\
\hline AST (units/L) & $3-34$ & 29 & NA & 340 & 378 & 460 & 61 & 29 \\
\hline ALT (units/L) & $15-41$ & 33 & NA & 579 & 644 & 770 & 273 & 70 \\
\hline ALP (units/L) & $38-126$ & 78 & NA & 89 & 104 & 103 & 119 & 97 \\
\hline \multicolumn{9}{|c|}{ Bilirubin (mg/dL) } \\
\hline Total & $0.02-1.3$ & 0.3 & NA & 0.7 & 0.5 & 0.4 & 0.4 & 0.5 \\
\hline Direct & $0.0-0.3$ & NA & NA & 0.10 & 0.10 & 0.10 & NA & NA \\
\hline R ratio ${ }^{b}$ & & & & 19.99 & & & & \\
\hline RUCAM score ${ }^{c}$ & & & & 10 & & & & \\
\hline
\end{tabular}

$A L P$ alkaline phosphatase, $A L T$ alanine transaminase, $A S T$ aspartate transaminase, INR international normalized ratio, $N A$ not available, RUCAM Roussel Uclaf Causality Assessment Method, $U L N$ upper limit of normal

${ }^{a}$ Enoxaparin was initiated on day 1 and continued until day 7. Fondaparinux was initiated on day 7 and continued

b $\mathrm{R}$ ratio: (ALT value $\div$ ALT $\mathrm{ULN}) \div($ Alk $\mathrm{P}$ value $\div$ Alk $\mathrm{P}$ ULN). $\mathrm{R}$ ratios of $>5$ : hepatocellular injury, $<2$ : cholestatic injury, 2-5: mixed pattern of injury

${ }^{c}$ RUCAM score: Type of liver injury: hepatocellular; time of onset of the event: first exposure; time from drug intake until reaction onset: $<5$ to $>90$ days ( +1 points); time from drug withdrawal until reaction onset: $\leq 15$ days $(+1$ point $)$; alcohol risk factor: absent ( 0 points); age risk factor: $<55$ years $(0$ points); course of reaction: $>50 \%$ improvement 8 days ( +3 points); concomitant therapy: time to onset compatible but known reaction $(+2$ points); exclusion of nondrug-related causes: ruled out $(+2$ points $)$; previous information: reaction labeled in the product's characteristics ( +2 points); response to re-administration: positive $(+3$ points) decreased to 61 and $273 \mathrm{U} / \mathrm{L}$, respectively. The patient continued to be asymptomatic, and on day 22, the AST had normalized to $29 \mathrm{U} / \mathrm{L}$ and the ALT had decreased to $70 \mathrm{U} /$ L. A RUCAM score was calculated to be 10 points, giving a highly probable likelihood that enoxaparin was the cause of hepatic injury.

Subsequently, an evaluation of the patient's hypercoagulable state disclosed the finding of adenocarcinoma in the large intestine for which he underwent appropriate treatment. Fondaparinux was continued throughout the duration of his colon cancer treatment without any effect on liver-associated enzymes (LAEs). The patient provided written informed consent for the publication of this case report.

\section{Literature Review of Enoxaparin and Other Anticoagulants}

\section{Methods}

A literature search was conducted using standard DILI terms and cross-referenced with the anticoagulant classes to identify cases of DILI by drug class. The standard DILI terms used in the query prompt included hepatitis, liver injury, hepatocellular injury, drug injury, hepatic injury, and injury. Search terms for the heparin class included any reports on UFH or the following three LMWH agents approved by the FDA: enoxaparin, dalteparin, and tinzaparin. HAEs related to coumarins or warfarin, as well as DILI attributed to factor Xa inhibitors (specifically apixaban and rivaroxaban) were also collected. Synthetic factor $\mathrm{Xa}$ inhibitors such as fondaparinux, and marketed direct thombin inhibitors like dabigatran were also queried.

Only papers printed in English that discussed DILI in relation to these anticoagulants were reviewed. The search dates were from 1975 to December 2014, which covers the time since the first published case reports of anticoagulantrelated DILI [6, 8, 19]. The literature searches were based on the following search engines: MEDLINE/Pubmed, Livertox, and Google Scholar.

\section{Results}

Results of the literature search on each of the anticoagulants are summarized in Table 2. Previous studies showed that coumarins, factor Xa inhibitors, and recently approved direct thrombin inhibitors rarely cause injury, with a frequency of DILI ranging from 1 to $3 \%$ based on clinical trial data [7, 11-14]. Liver injury was considered mild to moderate in severity, self-limited, and largely asymptomatic. Discontinuations of the suspected drug always led to resolution of 
Table 2 Drug-induced liver injury (DILI) characteristics summarized by anticoagulant drug class ${ }^{\mathrm{a}}$

\begin{tabular}{|c|c|c|c|c|c|c|}
\hline Drug & Onset & Half life (h) & Abnormal values & Mechanism of action & $\begin{array}{l}\text { Frequency } \\
(\%)\end{array}$ & $\begin{array}{l}\text { Severity and } \\
\text { symptoms }\end{array}$ \\
\hline \multicolumn{7}{|c|}{ Vitamin $\mathrm{K}$ antagonists/coumarins } \\
\hline $\begin{array}{l}\text { Warfarin } \\
\text { (Coumadin) [7, } \\
11]\end{array}$ & $\begin{array}{l}\text { Within } 3-8 \text { weeks } \\
\text { of starting } \\
\text { therapy; rare } \\
\text { instances after } \\
\text { months or years } \\
\text { of therapy }\end{array}$ & $20-60$ & $\begin{array}{l}\text { Typically cholestatic, } \\
\text { but hepatocellular } \\
\text { and mixed patterns } \\
\text { reported }\end{array}$ & $\begin{array}{l}\text { Not known, } \\
\text { idiosyncratic; } \\
\text { possibly } \\
\text { immunologic }\end{array}$ & $1-3$ & $\begin{array}{l}\text { Mild to moderate in } \\
\text { severity; self- } \\
\text { limited. Resolves } \\
\text { once therapy is } \\
\text { stopped. Recurrence } \\
\text { of liver injury } \\
\text { usually occurs with } \\
\text { rechallenge, which } \\
\text { should be avoided }\end{array}$ \\
\hline \multicolumn{7}{|c|}{ Heparin and derivatives } \\
\hline $\begin{array}{l}\text { Unfractionated } \\
\text { heparin } \\
\text { (Heparin) }[4,9]\end{array}$ & $\begin{array}{l}\text { Within } 4-8 \text { days of } \\
\text { starting therapy }\end{array}$ & 1.5 & $\begin{array}{l}\text { Hepatocellular pattern } \\
\text { of serum ALT and } \\
\text { AST elevated; } \\
\text { alkaline phosphatase } \\
\text { is elevated in a small } \\
\text { proportion }\end{array}$ & $\begin{array}{l}\text { Likely direct toxic } \\
\text { effect on } \\
\text { hepatocytes }\end{array}$ & $\sim 8$ & $\begin{array}{l}\text { Asymptomatic and } \\
\text { self-limited; lasting } \\
4-20 \text { days and } \\
\text { resolves sometimes } \\
\text { despite continuation } \\
\text { of treatment }\end{array}$ \\
\hline $\begin{array}{l}\text { LMWH } \\
\text { (enoxaparin/ } \\
\text { Lovenox, } \\
\text { dalteparin/ } \\
\text { Fragmin, } \\
\text { tinzaparin/ } \\
\text { Innohep) [4, } \\
\text { 10, 33, 34] }\end{array}$ & $\begin{array}{l}\text { Within 3-7 days of } \\
\text { starting therapy }\end{array}$ & $\begin{array}{l}\text { Enoxaparin: } \\
\text { 3-5 } \\
\text { Dalteparin: } \\
\text { 3-5 } \\
\text { Tinzaparin: } \\
\text { 3-4 }\end{array}$ & $\begin{array}{l}\text { Hepatocellular pattern } \\
\text { of serum ALT and } \\
\text { AST elevated; rare } \\
\text { increases in bilirubin }\end{array}$ & $\begin{array}{l}\text { Likely direct toxic } \\
\text { effect on } \\
\text { hepatocytes }\end{array}$ & $4-13$ & $\begin{array}{l}\text { Asymptomatic and } \\
\text { self-limited; } \\
\text { resolves rapidly } \\
\text { upon stopped } \\
\text { therapy. Elevation in } \\
\text { liver enzymes may } \\
\text { improve with dose } \\
\text { adjustment and } \\
\text { sometimes resolve } \\
\text { despite continuation } \\
\text { of treatment using } \\
\text { the same dose. } \\
\text { Recurrence of liver } \\
\text { injury with } \\
\text { restarting therapy is } \\
\text { invariable and the } \\
\text { clinical implications } \\
\text { of these } \\
\text { abnormalities are } \\
\text { not clear }\end{array}$ \\
\hline \multicolumn{7}{|c|}{ Factor Xa inhibitors (synthetic and direct) } \\
\hline $\begin{array}{l}\text { Fondaparinux; } \\
\text { synthetic } \\
\text { (Atrixtra) [12] }\end{array}$ & Not known & $17-21$ & $\begin{array}{l}\text { Hepatocellular pattern } \\
\text { of serum ALT and } \\
\text { AST elevations; can } \\
\text { be more than } 3 \times \\
\text { ULN }\end{array}$ & $\begin{array}{l}\text { Likely direct toxic } \\
\text { effect on } \\
\text { hepatocytes }\end{array}$ & $1-3$ & $\begin{array}{l}\text { Self-limited and does } \\
\text { not require dose } \\
\text { modification or } \\
\text { discontinuation of } \\
\text { therapy }\end{array}$ \\
\hline $\begin{array}{l}\text { Rivaroxaban; } \\
\text { direct (Xarelto) } \\
\text { [13] }\end{array}$ & Not known & $5-9$ & $\begin{array}{l}\text { Hepatocellular pattern } \\
\text { of serum ALT and } \\
\text { AST elevations. } \\
\text { Rare instances of } \\
\text { clinically apparent } \\
\text { liver injury with } \\
\text { jaundice. Chronic } \\
\text { therapy associated } \\
\text { with moderate ALT } \\
\text { elevations; varies } \\
\text { from mild serum } \\
\text { ALT elevations to } \\
\text { liver injury with } \\
\text { jaundice }\end{array}$ & Not known & $1-3$ & $\begin{array}{l}\text { Mild and self-limited; } \\
\text { resolving within a } \\
\text { few weeks of } \\
\text { stopping therapy }\end{array}$ \\
\hline
\end{tabular}


Table 2 continued

\begin{tabular}{|c|c|c|c|c|c|c|}
\hline Drug & Onset & Half life (h) & Abnormal values & Mechanism of action & $\begin{array}{l}\text { Frequency } \\
(\%)\end{array}$ & $\begin{array}{l}\text { Severity and } \\
\text { symptoms }\end{array}$ \\
\hline $\begin{array}{l}\text { Apixaban; } \\
\text { direct (Eliquis) } \\
{[14]}\end{array}$ & Not known & 12 & $\begin{array}{l}\text { Hepatocellular pattern } \\
\text { of serum ALT and } \\
\text { AST elevations; can } \\
\text { be more than } 3 \times \\
\text { ULN }\end{array}$ & Not known & $1-3$ & $\begin{array}{l}\text { Mild and rapidly } \\
\text { reversible, often } \\
\text { even without } \\
\text { stopping therapy }\end{array}$ \\
\hline \multicolumn{7}{|c|}{ Direct thrombin inhibitors } \\
\hline $\begin{array}{l}\text { Dabigatran } \\
\text { etexilate } \\
\text { (Pradaxa) [15] }\end{array}$ & $\begin{array}{l}\text { Not known; some } \\
\text { case reports } \\
\text { estimate within } 4 \\
\text { weeks of starting } \\
\text { therapy }\end{array}$ & $12-17$ & $\begin{array}{l}\text { Hepatocellular pattern } \\
\text { of serum ALT and } \\
\text { AST elevations. } \\
\text { Rare jaundice; some } \\
\text { case reports of } \\
\text { elevated bilirubin, } \\
\text { giving a mixed } \\
\text { pattern. Chronic } \\
\text { therapy associated } \\
\text { with moderate ALT } \\
\text { elevations more than } \\
3 \times \text { ULN }\end{array}$ & $\begin{array}{l}\text { Not known; may be } \\
\text { idiosyncratic or } \\
\text { immunologic }\end{array}$ & $1.5-3$ & $\begin{array}{l}\text { Mild and self-limited; } \\
\text { resolving } \\
\text { completely once } \\
\text { stopping therapy. } \\
\text { Resolution can take } \\
\text { as long as } 4 \text { weeks. } \\
\text { Recurrence of liver } \\
\text { injury with } \\
\text { rechallenge has not } \\
\text { been described }\end{array}$ \\
\hline $\begin{array}{l}\text { Ximelagatran } \\
\text { (Exanta, } \\
\text { Exarta) }[16]\end{array}$ & $\begin{array}{l}\text { Within 1-6 months; } \\
\text { typically occurs } \\
\text { after more than } 35 \\
\text { days of use, with } \\
\text { highest peak in } \\
\text { second or third } \\
\text { month of } \\
\text { treatment }\end{array}$ & $3-5$ & $\begin{array}{l}\text { Hepatocellular pattern } \\
\text { of serum ALT and } \\
\text { AST elevations can } \\
\text { be }>3 \times \text { ULN. } \\
\text { Occasionally with } \\
\text { elevated total } \\
\text { bilirubin }>2 \times \text { ULN }\end{array}$ & $\begin{array}{l}\text { Not known; may be } \\
\text { related to } \\
\text { immunological } \\
\text { pathogenesis as } \\
\text { increased risk of } \\
\text { serum ALT } \\
\text { elevations linked to } \\
\text { HLA-DRB } 1 * 07 \text { and } \\
\text { DQA } 1 *-02\end{array}$ & $5-6$ & $\begin{array}{l}\text { Potentially severe and } \\
\text { fatal course; } \\
\text { resolution can occur } \\
\text { initially once } \\
\text { therapy stopped, but } \\
\text { hepatic damage can } \\
\text { present after } \\
\text { unknown periods } \\
\text { subsequent to } \\
\text { withdrawal of drug }\end{array}$ \\
\hline
\end{tabular}

$A L T$ alanine transaminase, $A S T$ aspartate transaminase, $L M W H$ low molecular weight heparin, $U L N$ upper limit of normal

${ }^{\text {a }}$ References for each anticoagulant correspond with those in manuscript

the liver injury, and in some instances, aminotransferases normalized despite continuation of treatment. In contrast, UFH and LMWH caused higher rates of liver injury, 8 and $4-13 \%$, respectively, as noted in their package inserts summarizing clinical trial results $[9,10]$.

A literature search specifically aimed at identifying enoxaparin-related HAEs revealed a total of five published reports [4, 23-26]. Table 3 provides the clinical details of these cases, in addition to our patient. The series by Harrill et al. describes the details of 12 subjects with enoxaparininduced liver injury [26]. In that trial, a total of 48 healthy subjects were randomized to four groups and received standard doses of subcutaneously administered UFH at $150 \mathrm{U} / \mathrm{kg}$, enoxaparin at $1 \mathrm{mg} / \mathrm{kg}$, dalteparin at $120 \mathrm{IU} / \mathrm{kg}$, or adomiparin $125 \mathrm{IU} / \mathrm{kg}$ for 5 days [26]. Daily liver tests were drawn, and in 7 of the 12 men $(58.3 \%)$ who received enoxaparin, elevations in AST and ALT were seen starting on day 3. By day 6, all 12 subjects had aminotransferase elevations above $3 \times$ ULN [26]. Six days after enoxaparin was discontinued (day 12 of the study), all participants had normalization of AST and ALT. Unfortunately, no follow up data, specific patient demographic information, or symptoms were provided in the study report.

Hui et al. described a 26-year-old female patient with asymptomatic elevations in AST and ALT, 4 days after starting enoxaparin [23]. The patient also started clarithromycin and cefepime at the same time for the treatment of pneumonia. The antibiotics were stopped after 1 week, but enoxaparin was continued. The rises in aminotransferases along with alkaline phosphatase and GGT remained stable for the duration of the first month. At the end of 60 days, enoxaparin was discontinued. One week later, there was a fall in AST to $73 \mathrm{U} / \mathrm{L}$, ALT to $152 \mathrm{U} / \mathrm{L}$, and alkaline phosphatase to $128 \mathrm{U} / \mathrm{L}$. A percutaneous liver biopsy was performed and showed preservation of acinar architecture, with ballooning degeneration, and cytoplasmic swelling mainly in zone 3 with focal changes in zone 2. Following the liver biopsy, the patient was restarted on enoxaparin at the same initial dose. Two weeks after this re-exposure, similar abnormalities in LAEs were recorded. The patient was switched to warfarin and liver tests returned to normal over the next 2 months. 


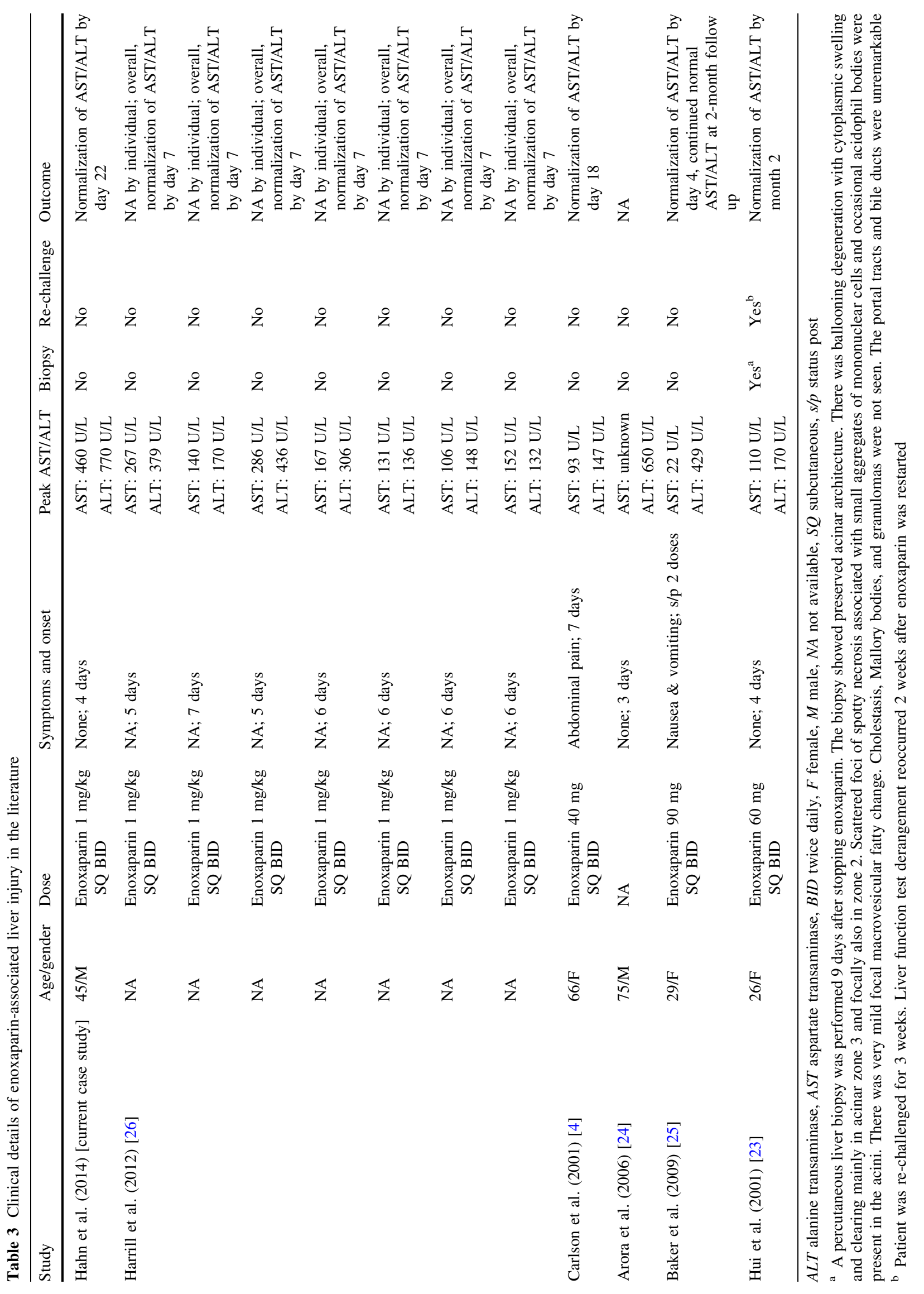


Another case reported by Baker et al. describes a 29-year-old female who developed an ALT of $400 \mathrm{U} / \mathrm{L}$ after just two doses of enoxaparin [25]. The patient was symptomatic with nausea and vomiting. Her symptoms and liver enzyme elevations resolved quickly after enoxaparin was discontinued. The other four publications were individual case reports with varying amounts of information regarding the hepatic event.

\section{Other Low Molecular Weight Heparins (LMWH)}

A review of the published literature regarding the two other FDA-approved LMWH products, dalteparin and tinzaparin, was also undertaken. Two published reports of liver injury attributed to dalteparin were found [26, 27]. The clinical details are summarized in Table 4 . No cases of tinzaparinrelated HAEs were found in our literature search. In the series by Harrill et al., 7 of $12(58.3 \%)$ healthy men given dalteparin (120 IU/kg for 5 days) developed elevations in AST and ALT of at least $3 \times$ ULN starting on days 6 and 7 [26]. However, by day 12, 1 week after dalteparin was discontinued, these liver tests were seen to be declining [26]. As with enoxaparin, no follow-up data, specific patient demographics, or information on symptoms were provided for this subgroup in the study. Similar to enoxaparin, dalteparin-related liver injury also appeared to be mild in severity and reversible.

An individual case report of suspected dalteparin DILI was described in a male with alpha- 1 antitrypsin deficiency (AATD) and normal baseline liver tests [27]. He developed symptomatic elevations in aminotransferases 30 days after starting the anticoagulant, with peak values of AST of $500 \mathrm{U} / \mathrm{L}$ and ALT of approximately $900 \mathrm{U} / \mathrm{L}$. On day 42, dalteparin was discontinued. A percutaneous liver biopsy performed on day 43 showed condensation of the reticulum network and expanded portal tracts mainly due to proliferating bile ducts and infiltrates of inflammatory cells. In addition, loss and necrosis of liver cells was described mainly in zone 3. Hepatocytes showed ballooning and cytoplasmic swelling; signs of intracellular cholestasis were also found. At follow up 5 months later (day 191), the patient's AST and ALT had completely normalized. The

Table 4 Clinical details of dalteparin-associated liver injury in the literature

\begin{tabular}{|c|c|c|c|c|c|c|c|}
\hline Study & Age/gender & Dose & $\begin{array}{l}\text { Symptoms and } \\
\text { onset }\end{array}$ & Peak AST/ALT & Biopsy & Rechallenge & Outcome \\
\hline \multirow[t]{7}{*}{$\begin{array}{l}\text { Harrill et al. } \\
\text { (2012) [26] }\end{array}$} & NA & $\begin{array}{l}\text { Dalteparin } \\
120 \mathrm{IU} / \mathrm{kg} \\
\text { SQ BID }\end{array}$ & NA; 4 days & $\begin{array}{l}\text { AST: } 320 \mathrm{U} / \mathrm{L} \\
\text { ALT: } 757 \mathrm{U} / \mathrm{L}\end{array}$ & No & No & $\begin{array}{l}\text { Normalization of AST/ALT by } \\
\text { month } 5\end{array}$ \\
\hline & NA & $\begin{array}{l}\text { Dalteparin } \\
120 \mathrm{IU} / \mathrm{kg} \\
\text { SQ BID }\end{array}$ & NA; 5 days & $\begin{array}{l}\text { AST: } 241 \mathrm{U} / \mathrm{L} \\
\text { ALT: } 415 \mathrm{U} / \mathrm{L}\end{array}$ & No & No & $\begin{array}{l}\text { NA by individual; overall, } \\
\text { normalization of AST/ALT by } \\
\text { day } 7\end{array}$ \\
\hline & NA & $\begin{array}{l}\text { Dalteparin } \\
120 \mathrm{IU} / \mathrm{kg} \\
\text { SQ BID }\end{array}$ & NA; 7 days & $\begin{array}{l}\text { AST: } 149 \mathrm{U} / \mathrm{L} \\
\text { ALT: } 238 \mathrm{U} / \mathrm{L}\end{array}$ & No & No & $\begin{array}{l}\text { NA by individual; overall, } \\
\text { normalization of AST/ALT by } \\
\text { day } 7\end{array}$ \\
\hline & NA & $\begin{array}{l}\text { Dalteparin } \\
120 \mathrm{IU} / \mathrm{kg} \\
\text { SQ BID }\end{array}$ & NA; 6 days & $\begin{array}{l}\text { AST: } 131 \mathrm{U} / \mathrm{L} \\
\text { ALT: } 233 \mathrm{U} / \mathrm{L}\end{array}$ & No & No & $\begin{array}{l}\text { NA by individual; overall, } \\
\text { normalization of AST/ALT by } \\
\text { day } 7\end{array}$ \\
\hline & NA & $\begin{array}{l}\text { Dalteparin } \\
120 \mathrm{IU} / \mathrm{kg} \\
\text { SQ BID }\end{array}$ & NA; 6 days & $\begin{array}{l}\text { AST: } 202 \mathrm{U} / \mathrm{L} \\
\text { ALT: } 377 \mathrm{U} / \mathrm{L}\end{array}$ & No & No & $\begin{array}{l}\text { NA by individual; overall, } \\
\text { normalization of AST/ALT by } \\
\text { day } 7\end{array}$ \\
\hline & NA & $\begin{array}{l}\text { Dalteparin } \\
120 \mathrm{IU} / \mathrm{kg} \\
\text { SQ BID }\end{array}$ & NA; 6 days & $\begin{array}{l}\text { AST: } 155 \mathrm{U} / \mathrm{L} \\
\text { ALT: } 269 \mathrm{U} / \mathrm{L}\end{array}$ & No & No & $\begin{array}{l}\text { NA by individual; overall, } \\
\text { normalization of AST/ALT by } \\
\text { day } 7\end{array}$ \\
\hline & NA & $\begin{array}{l}\text { Dalteparin } \\
120 \mathrm{IU} / \mathrm{kg} \\
\text { SQ BID }\end{array}$ & NA; 7 days & $\begin{array}{l}\text { AST: } 96 \mathrm{U} / \mathrm{L} \\
\text { ALT: } 165 \mathrm{U} / \mathrm{L}\end{array}$ & No & No & $\begin{array}{l}\text { NA by individual; overall, } \\
\text { normalization of AST/ALT by } \\
\text { day } 7\end{array}$ \\
\hline $\begin{array}{l}\text { Levinson } \\
\text { et al. (2012) } \\
\text { [27] }\end{array}$ & $52 / \mathrm{M}$ & $\begin{array}{l}\text { Dalteparin } \\
15,000 \text { IU } \\
\text { SQ QD }\end{array}$ & $\begin{array}{l}\text { Fever, nausea, } \\
\text { jaundice; } 30 \\
\text { days }\end{array}$ & $\begin{array}{l}\text { AST: } 500 \mathrm{U} / \mathrm{L} \\
\text { ALT: } 900 \mathrm{U} / \mathrm{L}\end{array}$ & $\mathrm{Yes}^{\mathrm{a}}$ & No & \\
\hline
\end{tabular}

$A L T$ alanine transaminase, $A S T$ aspartate transaminase, $B I D$ twice daily, $F$ female, $M$ male, $N A$ not available, $Q D$ every day, $S Q$ subcutaneous

${ }^{a}$ A percutaneous liver biopsy was performed on day 43. Dalteparin treatment had been discontinued on day 42 . The biopsy showed condensation of the reticulum network and expanded portal tracts due to proliferating bile ducts and infiltrates of inflammatory cells. Loss and necrosis of liver cells, ballooning and cytoplasmic swelling, and signs of intracellular cholestasis were also seen. A second biopsy performed at follow-up visit 5 months after the initial biopsy showed almost complete remission of bile duct proliferation and no remaining signs of the presumed toxic and cholestatic hepatitis 
authors were uncertain as to the mechanism of injury, but theorized that adults with AATD may be more susceptible to DILI [27].

In addition to case reports in the literature, we reviewed the safety of LMWH compounds in their respective preclinical development programs. None of the pre-clinical toxicology reports, however, suggested that the liver was a target for LMWH in either rodents or dogs [28]. In fact, research in animals has demonstrated that heparins can mitigate against liver injury in some rat models [28]. Nevertheless, animal toxicology studies are known to correlate poorly with human DILI [20, 29]; as many as $40 \%$ of known human hepatotoxins were not identified in pre-clinical toxicology studies [20, 30].

\section{Review of the FAERS Database for LMWH}

\section{Methods}

In addition to our literature review, through a Freedom of Information Act (FOIA) request, we performed an analysis of the adverse hepatic events linked to enoxaparin contained in the FAERS database for a 14-year period (January 2000-September 2014). HAEs were identified using the following specific terms: hepatocellular injury, hepatitis, hepatic injury, and liver abnormalities. Case type, severity of outcome, and other demographic information were reported through the FAERS protocol. Cases were classified as one of three types: expedited (serious, unexpected events), non-expedited (non-urgent adverse events submitted by the manufacturer), or direct (non-urgent adverse events submitted by healthcare providers or patients). Outcome severity was categorized as resulting in either death, hospitalization, a life-threatening medical event, another serious important event or disability, or the need for intervention. Dosage information for enoxaparin was divided into $\leq 120$ or $\geq 120 \mathrm{mg}$ given subcutaneously per day. Duration of usage was categorized as $<2$ or $>2$ weeks. Concomitant polypharmacy was defined as greater than or equal to four medications in addition to enoxaparin. HAEs were analyzed using logistic regression and frequency tabulations [31].

\section{Results}

Our enoxaparin FOIA request yielded 8336 adverse events reported from January 2000 through September 2014. The number of patients with specific HAEs was $311(3.7 \%$ of the total). Of those, 281 (93\%) were classified as expedited reports, $9(3 \%)$ as non-expedited, and $13(4 \%)$ as direct. The majority of cases were reported from France (97\%). A slight majority of HAEs occurred in women
$(51 \%)$ and the mean age of all patients was 56.7 years. For these 311 patients, the most commonly reported outcomes were hospitalization (75\%), death (17\%), and lifethreatening medical events $(5 \%)$. However, all HAEs were reported as one of several concomitant adverse events, and were not reported as isolated adverse events. Since we were not provided with any individual case details, we were unable to correlate the reported outcomes with the specific occurrence of a HAE.

Overall, the most commonly reported AEs were hemorrhage in $28 \%$ and thrombocytopenia in $11 \%$. These serious adverse events likely had a more important bearing on the need for hospitalization, death, and other serious medical outcomes than did any of the HAEs. In addition, the clinical indications for anticoagulation were also not available for our review. However, given the high rate of bleeding reported, it would appear that death and other serious outcomes were more likely to be related to these common AEs and other patient comorbidities. Patients on higher doses of enoxaparin were more likely to have serious outcomes or death (OR 2.29; $95 \%$ CI 0.90-5.82). Similarly, longer duration of therapy increased the odds of hospitalization (OR 1.30; $95 \%$ CI 0.36-4.64). Polypharmacy was also associated with a slightly higher chance of death among these patients (OR 1.10; $95 \%$ CI 0.55-2.20).

\section{Discussion}

DILI caused by anticoagulants dates back more than 40 years [5, 25]. Hepatotoxicity attributed to the heparin subclass was first described in 1975 [5, 25, 32]. The three LMWH approved in the US to date include enoxaparin (1993), dalteparin (1994), and tinzaparin (2000) [10, 33, 34]. HAEs caused by heparin have been well documented $[4,35]$. The hepatic injury pattern caused by both UFH and LWMH appears similar, with mostly asymptomatic elevations in aminotransferases without concomitant changes in bilirubin. Most patients, like ours, have aminotransferase elevations in the first week of usage and normalization of LAEs quickly follows discontinuation. The majority of anticoagulant-related DILI have a hepatocellular pattern of injury. The one exception is the case reported by Hui et al., which showed a mixed pattern but was also confounded by the concomitant use of antibiotics [23]. Coumarins typically produce cholestatic injury $[11,36]$. Regardless of the agent or the injury pattern, anticoagulant-associated DILI is generally mild.

The exception among anticoagulant-associated DILI remains ximelagatran, an oral direct thrombin inhibitor, which was found to cause severe hepatic injury (with several cases meeting Hy's Law criteria) in longer-term clinical trials [16]. Subsequent pharmacogenomic studies 
[37] identified a genetic predisposition for ximelagatranrelated DILI. While the exact cause of injury remains unknown, patients with HLA-DRB1*07 and DQA1*02 genotypes have an increased risk of developing serum ALT elevations, possibly through an activation of the host's immune response [37-39]. To our knowledge, such HLA or other genetic predispositions have not been evaluated in other anticoagulant classes.

With enoxaparin, instances of DILI often occur within 1 week of starting therapy, representing a very short latency period. Patients are generally asymptomatic and without hypersensitivity features such as fever, skin rash, or eosinophilia [4]. Given the frequency of LMWH-related ALT elevations, in the absence of a clear immunoallergic mechanism, it is believed that heparins may have a direct toxic effect on the liver, as suggested by Harrill et al. [26]. The histopathology from single cases receiving enoxaparin and dalteparin point to the presence of a predominantly hepatocellular form of injury [23]. The absence of serum plasma cells or eosinophils argue against an immune/allergy etiology; however, the number of cases with liver biopsies is too small to draw any firm conclusions [23].

A recent study focusing on biomarkers of DILI further supports the possibility that a direct toxic effect on the hepatocyte causes the hepatocellular injury reported with enoxaparin [26]. Heparins have not been shown to form reactive metabolites [5]. Harrill and colleagues have proposed that leakage of specific hepatic intracellular biomarkers, such as miR-122, into the serum after enoxaparin exposure suggests that this agent causes transient hepatocyte necrosis [23, 24, 26]. In addition, research has shown an increase in HMGB1, a protein associated with damage in necrotic cells, following the usage of heparin [26]. The peaking of both miR-122 and HMGB1 in the days following heparin usage is consistent with the belief that LMWH such as enoxaparin directly injure the hepatocyte, resulting in necrosis [26]. Such direct injury is confirmed by the frequency of enoxaparin-related ALT and AST as shown by Harrill et al., where more than $50 \%$ of healthy subjects started on enoxaparin developed DILI within 1 week and all were affected by day 12 [26]. As the frequency and dosing of enoxaparin increases, so too does the magnitude of aminotransferase elevations [40, 41], raising the possibility of dose-related injury.

For heparins, hepatoxicity is the most frequently reported adverse event. The information compiled in the National Library of Medicine's LiverTox database [42] notes that liver injury is responsible for $8 \%$ of adverse events from UFH and 4-13\% from LMWH based on clinical trial data $[9,10]$. A review of the FAERS database further corroborates this frequency, with approximately $4 \%$ of all enoxaparin-related adverse events involving the liver. Liver toxicity, however, was not reported to be an isolated AE in FAERS, as HAEs were always associated with other, more serious events. The majority of reported LMWH-related HAEs in FAERS were reported from France, however the reason for this is uncertain.

While higher dosage and longer duration of enoxaparin were more likely to lead to hospitalization and/or death, these serious outcomes are likely the result of hemorrhage or other severe AEs coupled with the underlying patient comorbidities requiring anticoagulation. The relatively small proportion of patients listed as having HAEs, combined with the generally mild clinical course and reversible nature of DILI described in the published literature, suggests that the HAEs by themselves are unlikely to have contributed significantly to the morbidity and mortality reported in FAERS. Similarly, the polypharmacy associated with a higher risk of death in patients on enoxaparin also likely reflects the numerous comorbidities that affect such patients.

Our case is consistent with the clinical signature that has emerged for enoxaparin liver injury as reported in previous case reports. Characteristically, enoxaparin DILI has a short latency and rapid reversibility, without accompanying hypersensitivity symptoms such as fever, rash, or eosinophilia. In our patient, aminotransferase elevations peaked by day 7 and began to normalize quickly thereafter. While the peak values were higher than those in other published reports, liver injury had completely resolved after the drug was discontinued. Of note, the fondaparinux that replaced enoxaparin on day 7 was found to have no cross reactivity, as liver tests remained normal. Other novel oral anticoagulants may also be good alternatives in treatment of venous thrombosis, as they to do not require a 'bridge therapy' and have lower rates of HAE [43, 44]. Given that a similar hepatic pattern of injury is associated with UFH, heparin-induced liver injury is presumed to be a class effect.

While FAERS is extremely useful in identifying potential new safety concerns, the reports submitted to the database are voluntary and do not require proven causal relationships between product and event [45]. Specifically, few reports have sufficient clinical and laboratory data to fully adjudicate an event. In addition, individual patient data and outcomes are not always available. This was the case for enoxaparin. Although the FAERS database can be supportive of the published literature for many individual agents, it cannot be used to calculate incidence data of an adverse event, such as DILI. Furthermore, the cause of the specific outcomes of hospitalization and death reported in relationship to enoxaparin cannot be definitively determined without an assessment of the complete medical record, for which we did not have access. More than likely, however, serious outcomes related to the underlying diseases requiring anticoagulation were the result of 
hemorrhage, thrombocytopenia, or other serious complications, rather than any of the hepatic AEs.

\section{Conclusion}

A review of the published literature of adverse events associated with enoxaparin indicates that up to $13 \%$ of reported AEs involve the liver [45]. The FAERS database estimates a frequency of $4 \%$ for HAEs, although these were always associated with other causes of morbidity and mortality, such as hemorrhage and thrombocytopenia. Enoxaparin-related liver injury has a short latency of approximately 1 week, and patients are usually asymptomatic without hypersensitivity features. The serious outcomes reported in FAERS, such as the need for hospitalization (75\%) and death (17\%), are most likely the result of the non-hepatic AEs. Similarly, the observation that higher dosages and longer duration of enoxaparin therapy, along with polypharmacy, are associated with such adverse outcomes are also more likely to be the result of non-hepatic causes.

In comparison with other forms of anticoagulation, enoxaparin-induced liver injury is similar to what has been reported with UFHs and several of the newer classes of anticoagulants. Severe DILI, however, appears to be unusual.

Acknowledgments Katherine Hahn, Shannon Morales, and James Lewis declare they have no conflicts of interest.

Open Access This article is distributed under the terms of the Creative Commons Attribution-NonCommercial 4.0 International License (http://creativecommons.org/licenses/by-nc/4.0/), which permits any noncommercial use, distribution, and reproduction in any medium, provided you give appropriate credit to the original author(s) and the source, provide a link to the Creative Commons license, and indicate if changes were made.

\section{References}

1. Weitz J. Low-molecular-weight heparins. $\mathrm{N}$ Engl J Med. 1997;337:688-99.

2. Hirsch J, Levine M. Low molecular weight heparin. Blood. 1992;79.

3. Bratt $\mathrm{G}$, et al. A comparison between low molecular weight heparin (KABI 2165) and standard heparin in the intravenous treatment of deep venous thrombosis. Thromb Haemost. 1985;54(4):813-7.

4. Carlson MK, Gleason PP, Sen S. Elevation of hepatic transaminases after enoxaparin use: case report and review of unfractionated and low-molecular-weight heparin-induced hepatotoxicity. Pharmacotherapy. 2001;21(1):108-13.

5. Olsson R, et al. Serum aminotransferases after low-dose heparin treatment. Short communication. Acta Med Scand. 1978;204(3):229-30.
6. Dukes GE Jr, et al. Transaminase elevations in patients receiving bovine or porcine heparin. Ann Intern Med. 1984;100(5):646-50.

7. Ehrenforth S, Schenk J, Scharrer I. Liver damage induced by coumarin anticoagulants. Semin Throm Hemost. 1999;25(1).

8. AL-Mekhaizeem KA, Sherker AH. Heparin-induced hepatotoxicity. Can J Gastroenterol. 2001;15(8):527-30.

9. Heparin Sodium, USP package insert. New York: Pfizer Global Manufacturing; 2009.

10. Lovenox (enoxaparin sodium injection) package insert. Bridgewater: Sanofi-Avetnis; 2013.

11. Coumadin (warfarin) package insert. Princeton: Bristol-Myers Squibb Pharma Company; 2014.

12. Arixtra (fondaparinux) package insert. Research Triangle Park: GlaxoSmithKline; 2013.

13. Xarelto (rivaroxaban) package insert. Titusville: Janssen Pharmaceuticals, Inc.; 2014.

14. Eliquis (apixaban) package insert. Princeton: E.R. Squibb \& Sons, L.L.C.; 2014.

15. Pradaxa (dabigatran etexilate mesylate) package insert. Ridgefield: Boehringer Ingelheim Pharmaceuticals Inc.; 2015.

16. Lee WM, et al. Hepatic findings in long-term clinical trials of ximelagatran. Drug Saf. 2005;28(4):351-70.

17. Lewis JH. 'Hy's law', the 'Rezulin Rule', and other predictors of severe drug-induced hepatotoxicity: putting risk-benefit into perspective. Pharmacoepidemiol Drug Saf. 2006;4:221-9.

18. AstraZeneca. AstraZeneca Decides to Withdraw Exanata. In: AstraZeneca Media Press Releases. February 14, 2006. http:// www.astrazeneca.com/Media/Press-releases/Article/20060214AstraZeneca-Decides-to-Withdraw-Exanta. Accessed 3 Feb 2015.

19. Moore TJ, Cohen MR, Furberg CD. Serious adverse drug events reported to the Food and Drug Administration, 1998-2005. Arch Intern Med. 2007;167(16):1752-9.

20. Lewis JH. Drug-induced liver injury throughout the drug development life cycle: where we have been, where we are now and where we are headed. Perspectives of a clinical hepatologist. Pharm Med. 2013;27:165-91.

21. Fagher B, Lundh B. Heparin treatment of deep vein thrombosis. Effects and complications after continuous or intermittent heparin administration. Acta Med Scand. 1981;210(5):357-61.

22. Benichou C, Danan G, Flahualt A. Causality assessment of adverse reactions to drugs-II. An original model for validation of drug causality assessment methods: case reports with positive rechallenge. J Clin Epidemiol. 1993;46(11):1331-6.

23. Hui $\mathrm{CK}$, et al. Low molecular weight heparin-induced liver toxicity. J Clin Pharmacol. 2001;41(6):691-4.

24. Arora N, Goldhaber SZ. Anticoagulants and transaminase elevation. Circulation. 2006;113(15):e698-702.

25. Baker EL, et al. Probable enoxaparin-induced hepatotoxicity. Am J Health Syst Pharm. 2009;66(7):638-41.

26. Harrill $\mathrm{AH}$, et al. The effects of heparins on the liver: application of mechanistic serum biomarkers in a randomized study in healthy volunteers. Clin Pharmacol Ther. 2012;92(2):214-20.

27. Levinson P, Glaumann H, Soderberg M. Probable dalteparin-induced hepatotoxicity in a man with alpha-1-antitrypsin deficiency. J Clin Pharmacol. 2012;52(11):1764-7.

28. Harada N, Okajima K, Uchiba M. Dalteparin, a low molecular weight heparin, attenuates inflammatory responses and reduces ischemia-reperfusion-induced liver injury in rats. Crit Care Med. 2006;34(7):1883-91.

29. Peters TS. Do preclinical testing strategies help predict human hepatotoxic potentials? Toxicol Pathol. 2005;33(1):146-54.

30. Zhang M, Chen M, Tong W. Is toxicogenomics a more reliable and sensitive biomarker than conventional indicators from rats to predict drug-induced liver injury in humans. Chem Res Toxicol. 2012;25(1):122-9. 
31. StataCorp. Stata Statistical Software: Release 11. College Station: StataCorp LP; 2009.

32. Sonnenblick M, Oren A, Jacobsonn W. Hypertransaminasemia with heparin therapy. Br Med J. 1975;3:77.

33. Innohep (tinzaparin sodium injection) package insert. Summit: Celegene Corporation; 2008.

34. Fragmin (dateparin sodium injection) package insert. Kalamazoo: Pharmacia \& Upjohn Company; 1998.

35. Francis JL, et al. Comparison of bovine and porcine heparin in heparin antibody formation after cardiac surgery. Ann Thorac Surg. 2003;75(1):17-22.

36. Adler E, Benjamin SB, Zimmerman HJ. Cholestatic hepatic injury related to warfarin exposure. Arch Intern Med. 1986;146(9):1837-9.

37. Urban TJ, Daly AK, Aithal GP. Genetic basis of drug-induced liver injury: present and future. Semin Liver Dis. 2014;34(2):123-33.

38. Kindmark A, et al. Genome-wide pharmacogenetic investigation of a hepatic adverse event without clinical signs of immunopathology suggests an underlying immune pathogenesis. Pharmacogenomics J. 2008;8(3):186-95.

39. Keisu M, Andersson TB. Drug-induced liver injury in humans: the case of ximelagatran. Handb Exp Pharmacol. 2010;196:407-18.

40. Freedman MD, et al. An evaluation of the biological response to fraxiparine (a low molecular weight heparin) in the healthy individual. J Clin Pharmacol. 1990;30(8):720-7.
41. Colwell CW Jr, et al. Use of enoxaparin, a low-molecular-weight heparin, and unfractionated heparin for the prevention of deep venous thrombosis after elective hip replacement. A clinical trial comparing efficacy and safety. Enoxaparin Clinical Trial Group. J Bone Jt Surg Am. 1994;76(1):3-14.

42. U.S. National Library of Medicine. Liver Disease Research Branch of the National Institute of Diabetes and Digestive and Kidney Diseases, Division of Specialized Information Services of the National Library of Medicine, National Institutes of Health. "Livertox Database". In: The National Library of Medicine, National Institutes of Health. 11 November 2014. http:// LiverTox.nih.gov. Accessed 12 Dec 2014.

43. Liakoni E, Rätz Bravo AE, Terracciano L, Heim M, Krähenbühl S. Symptomatic hepatocellular liver injury with hyperbilirubinemia in two patients treated with rivaroxaban. JAMA Intern Med. 2014;174:1683-6.

44. Russmann S, Niedrig DF, Budmiger M, et al. J Hepatol. 2014;61(2):293-300.

45. Szarfman A, Machado SG, O’Neill RT. Use of screening algorithms and computer systems to efficiently signal higher-thanexpected combinations of drugs and events in the U.S F.D.A's spontaneous reports database. Drug Saf. 2002;25(6):381-92. 